\title{
SOME EXPERIMENTAL OBSERVATIONS ON THE ACTION OF INTRAVENOUS HYPERTONIC UREA IN DOGS, WITH PARTICULAR REFERENCE TO PLASMA VOLUME AND TISSUE UREA CHANGES
}

\author{
BY
}

\author{
SHEDDEN ALEXANDER, J. C. EATON and H. J. FREEDMAN \\ From the Royal Infirmary, Glasgow
}

Several publications in recent years by Javid and his colleagues have reported on the use of hypertonic urea solutions to reduce the brain bulk in intracranial operations and to lower intracranial and intraocular tension (Javid, 1958a and b, 1959). That urea is a primary diuretic substance has long been known, but that the effect of hypertonic urea is not due to this diuretic action has been shown on nephrectomized monkeys (Javid and Anderson, 1959b). It has also been shown that the plasma electrolyte levels do not change appreciably (Garvin, Jennings, and Gesler, 1959).

Two explanations have been put forward to account for the shrinking action of urea on brain tissue. (1) A blood cerebrospinal fluid barrier is implicated by Javid and his colleagues: "The prolonged fall in cerebrospinal fluid pressure in nephrectomized monkeys is due to a prolonged osmotic pressure differential between blood and cerebrospinal fluid". (2) A blood-brain barrier, as originally postulated to exist by Weed and McKibben (1919), is implicated by Stubbs and Pennybacker (1960): "The reduction in brain bulk is obviously much greater than that of other soft tissues and we think that a barrier to the entry of urea into brain best explains our clinical observations".

The withdrawal of water from brain and cerebrospinal fluid must produce an increase in volume in some other compartment of the interstitial space and most writers acknowledge that the plasma volume rises and a state of hypervolaemia is induced (Tench, Javid, and Gilboe, 1960). We have not, however, encountered an assessment of this increase in plasma volume, and a neurosurgical case indicated that there was a very large increase in plasma volume. Estimations of plasma volume by the dye dilution technique in an average-sized adult patient who was given hypertonic urea before a neurosurgical operation revealed an increase in plasma volume of the order of 2 litres. This was far greater than could be accounted for even had all the water been removed from brain and cerebrospina $亡$ fluid and prompted us to question the blood-brain barrier explanation. To elucidate the point a smalf series of experiments in dogs was performed witto hypertonic urea infusions and the results are presented.

\section{Material and Method}

The plasma volume of three dogs was estimated bo measuring the dilution of Evans blue dye. Urevert ( $30 \%$ urea in $10 \%$ invert sugar) was infused intravenously, $\mathcal{C} . \xi$ g./kg. dog (Javid and Anderson, 1959a). Blood, muse्geve and brain samples were taken before, and at five, $\Psi_{0}$ and 15 minutes after infusion of the Urevert, upôtion 55 minutes, and urea, nitrogen, and water content determined. Muscle and brain urea were determined by homogenising the tissue, after weighing with a measured volume of water, centrifuging it, and measuring the urea content of the supernatant tissue fluid. Urine urea and urine flow rate were determined on samples from an indwelling urethral catheter. The femoral artery and vein were cannulated and blood pressure changes $\overrightarrow{\vec{s}}$ observed manometrically.

\section{Results}

The results are shown graphically in Fig. 1 where the rise in plasma volume is expressed as percentage of the initial volume. The absolute values for plasma volume are given in Table $\mathbf{I}$. The rapid, initial rise in plasma urea and its subses quent rate of fall is paralleled by the rapid initia rise in plasma volume and its subsequent fall $O$

TABLE I

ABSOLUTE INCREASES IN PLASMA VOLUME

\begin{tabular}{|c|c|c|c|}
\hline & $\underset{(22}{\operatorname{~kg} .)}{ }^{3}$ & $\underset{\text { (18 kg.) }}{\operatorname{Dog}}$ & $\begin{array}{r}\text { Dog. No } \\
\text { (23 kg.) }\end{array}$ \\
\hline $\begin{array}{l}\text { Initial plasma volume } \\
\text { (ml.) } \\
\text { Maximum increase in } \\
\text { plasma volume after } \\
\text { urea (ml.) }\end{array}$ & $\begin{array}{r}1,730 \\
910\end{array}$ & $\begin{array}{l}725 \\
155\end{array}$ & $\begin{array}{r}1,168 \\
548\end{array}$ \\
\hline
\end{tabular}


DOG No. 3

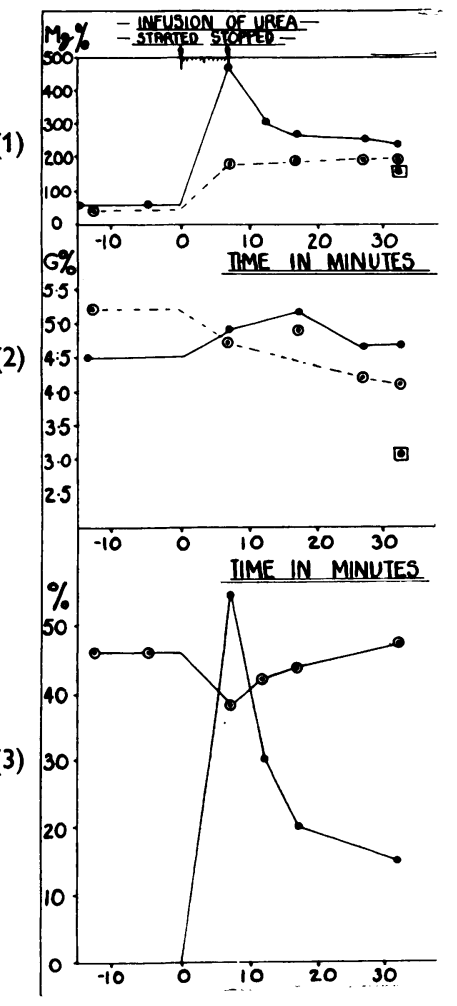

DOG No. 4

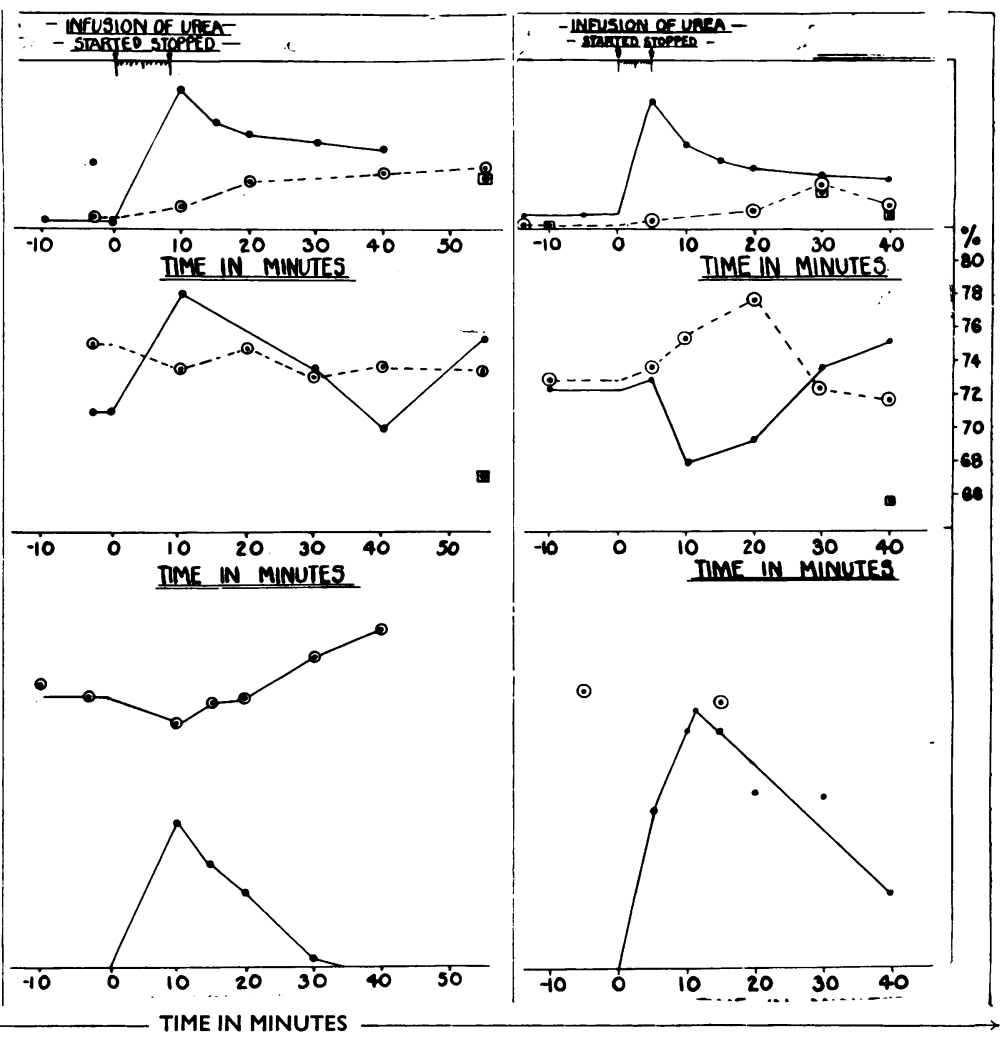

FIG. 1.-Graphs to show changes in plasma urea, plasma volume, haematocrit, muscle urea, brain urea, muscle nitrogen, and muscle water. Key to graphs

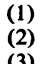

(2) :

Plasma urea

- - - - Muscle urea

$-\ldots$

Grain urea

Brain nitrogen

(3)

Increase in plasma volume as \%

- Haematocrit

\begin{tabular}{|c|c|c|c|c|c|c|}
\hline & \multicolumn{2}{|c|}{ Dog No. 3 (weight 22 kg.) } & \multicolumn{2}{|c|}{ Dog No. 4 (weight $18 \mathrm{~kg}$.) } & \multicolumn{2}{|c|}{ Dog No. 5 (weight 23 kg.) } \\
\hline & Before Urea & After Urea & Before Urea & After Urea & Before Urea & After Urea \\
\hline $\begin{array}{l}\text { Urine flow rate (ml./hr.) } \\
\text { Urine urea (g. \%) }\end{array}$ & $\begin{array}{l}37 \\
3.65\end{array}$ & $\begin{array}{r}187 \\
2.98\end{array}$ & 二 & $\overline{2 \cdot 35}$ & $\begin{array}{l}259 \\
2 \cdot 6\end{array}$ & $\begin{array}{l}75 \\
3 \cdot 26\end{array}$ \\
\hline
\end{tabular}

The haematocrit curve has been inserted since there was a considerable discrepancy in the rise in plasma volume calculated from the haematocrit, and the absolute rise determined by the Evans blue method, being much greater in the latter. The muscle urea will be seen to rise as the plasma urea falls, indicating that urea is entering muscle from plasma fairly quickly. In the first two dogs brain was sampled only at the end of the experiment, but it can be seen from brain urea levels that urea was also entering brain from plasma fairly quickly. The curves for muscle water and muscle nitrogen are best interpreted in conjunction with the curve for muscle urea. In dogs 3 and 5, as muscle urea rose, water rose and nitrogen fell. In dog 4 the relationship is less clearly seen.

The infusion in dog 3 produced a considerable diuresis. In dog 4 trouble with the catheter prevented full determinations, although the low urea concentration of the urine sample at the end of the experiment suggested that a diuresis had taken place. In dog 5 there was a very pronounced reduction in the flow of urine, the urine urea rose, and laparotomy at the conclusion of the experiment confirmed that the bladder was empty.

The lack of any continuous recording of arterial and venous pressures proved to be a disappointing omission where the time factor counted in such 
very short intervals. It was clear, however, that the central venous pressure rose immediately after infusion then fell to the initial level and that the arterial pressure dropped during this period, then returned to pre-urea levels. These changes conform to the known pattern of blood pressure changes after infusion of a concentrated electrolyte solution (Evans, 1930) but the failure to correlate them accurately in time with the other changes precludes any conclusion being based upon them.

\section{Discussion}

The absolute increase in plasma volume was of such a magnitude as to suggest a general withdrawal of fluid from body tissues. The figures for plasma urea, muscle urea, muscle nitrogen, and muscle water showed that water was leaving muscle and entering plasma so long as urea was more concentrated in plasma than in muscle and that when urea began to enter muscle in appreciable amounts water returned to muscle. It was apparent that urea was also entering brain at much the same rate and to the same degree as it was entering muscle, and that presumably a generalized blood-tissue osmotic gradient obtained. The deceptively large reduction in brain bulk seen when urea is infused in neurosurgical cases we would put down to the peculiar situation of brain in a rigid bone framework. These experiments lead us to discount the importance of a blood-brain barrier after the infusion of hypertonic urea and to postulate that a generalized blood-tissue osmotic gradient prevails.

In future experiments it is hoped to show to what extent changes occur in the volume of interstitial fluid and in plasma osmotic pressure. In these calculations the volume of solutes was neglected and in future it would be better to express the changes in water in the fluid compartments in terms of true water. The figure really required is the volume of plasma water not of plasma. A rise in blood urea of $327 \mathrm{mg}$. \% represents a rise of 54.5 mOsm. The normal osmolar value for mammalian plasma being of the order of 289 mOsm., this represents a rise of $18.9 \%$. Except in one dog when it was $20 \%$, the increase in plasma volume was? much greater than this which suggests that wheff water enters the extracellular fluid from cells ito carries with it other solutes, presumably to maintaim equilibrium between normal constituents in celk water and extracellular fluid.

The striking reduction in urine flow after urea infusion in one dog is attributed to renal haemo dynamic factors peculiar to the dog.

The disparity between the haematocrit and absolute plasma volume is attributed to the releases of red cells into the circulation from depots such aß the spleen.

\section{Summary and Conclusions}

Three dogs were infused with hypertonic urea $\overrightarrow{\xi_{\omega}}$ solution (Urevert). Determinations of water and? urea changes in plasma, muscle, and brain were made. "Water" in this context is used rather loosely as pointed out in the discussion.)

It is concluded that Urevert has a powerful and transitory effect in increasing plasma volume, and $\vec{\infty}$ that this effect is caused by the production of कs generalized blood tissue osmotic gradient and the consequent removal of water equally from different tissues.

We are grateful for permission to use facilities at Wellcome Research Laboratory, University of Glasg $\overline{\bar{e}} \bar{?}$

REFERENCES
Evans, C. Lovatt (1930). Starling's Principles of Human Physiology
5th ed., pp. 824-825. Churchill, London.
Garvin, P. J., Jennings, R. B., and Gesler, R. M. (1959). Pharmaco
logist, 1, No. 2.
Javid, M. (1958a). Surg. Clin. N. Amer., 38, 907.
(1958b). Mod. Med. (Minneap.), 26, 156.
(1959). Trans. Amer. neurol. Ass.,1958, p. 113 (83rd Annua
Meeting).
and Anderson, J. (1959a). Surg. Forum, 1958, 9, 686.
Stubbs, J., and Pennybacker, J. (1960). Lancet, 1, 1094.
Tench, J., Javid, M., and Gilboe, D. (1960). Anesthesiology, 21
Weed, L. H., and McKibben, P. S. (1919). Amer. J. Physiol., 48
512. (n) 